\title{
ANALISIS KONDISI GEOMETRIK JALAN TERHADAP POTEN- SI TERJADINYA KECELAKAAN LALU LINTAS
}

\author{
Nando Ramadhani Nur Adnan \\ Pranoto, Boedi Rahardjo
}

\begin{abstract}
Abstrak:Kondisi geometrik jalan yang tidak sesuai dengan standar teknis perencanaan dapat menyebabkan terjadinya kecelakaan lalu lintas. Tikungan SDN 3 Selorejo Kabupaten Blitar merupakan salah satu tikungan yang tidak memenuhi syarat perencanaan geometrik jalan di Indonesia. Penelitian ini menggunakan metode analisis deskriptif kuantitatif. Pengumpulan data dilakukan dengan metode survei lokasi selama 4 hari. Data primer meliputi data volume lalu lintas, kecepatan kendaraan, perlengkapan jalan, pelebaran jalan, dan geometrik jalan. Data sekunder data kecelakaan lalu lintas dan geometrik existing. Hasil penelitian mendapatkan: (1) karakteristik lalu lintas memiliki volume maksimum terjadi pada hari Senin sebesar $17221 \mathrm{smp} /$ hari yang di dominasi oleh kendaraan ringan (LV) sebesar 46,13\%, kecepatan kendaraan ratarata sebesar 47,95 km/jam dengan kecepatan tertinggi di dominasi oleh kendaraan bermotor (MC) yang memiliki rata-rata kecepatan sebesar $62,73 \mathrm{~km} /$ jam dengan kecepatan tertinggi yang pernah tercatat dalam pengamatan sebesar $87,64 \mathrm{~km} / \mathrm{jam}$, dan kepadatan kendaraan tertinggi terjadi pada hari Senin sebesar 32,73 smp/km, (2) kondisi geometrik jalan pada beberapa aspek perencanaan seperti nilai superelevasi existing memiliki nilai sebesar $11,50 \%$, sedangkan pada hasil perencanaan diperoleh superelevasi sebesar 9,89\%, lengkung peralihan existing memiliki panjang 40 meter, sedangkan pada hasil perencanaan diperoleh nilai lengkung peralihan sepanjang 54,56 meter, dan pelebaran jalan existing memiliki lebar jalan sebesar 0,3 meter, sedangkan pada hasil perencanaan diperoleh lebar jalan sebesar 0,7124 meter, (3) faktor-faktor penyebab kecelakaan di dominasi oleh faktor manusia sebesar 57,14\% dengan sebab kejadian yang sering dialami adalah kecepatan tinggi dan mengantuk, faktor kendaraan sebesar $21,43 \%$ dengan sebab kejadian yang dialami karena rem blong, muatan berlebih, dan ban pecah, sedangkan pada faktor jalan sebesar $21,43 \%$ yang selalu disebabkan oleh kemiringan jalan pada tikungan.
\end{abstract}

Kata-kata kunci: Geometrik Jalan, Tikungan, Faktor Kecelakaan, Lalu Lintas

Abstract: Geometric conditions that are not in accordance with the technical planning standards can cause traffic accidents. SDN 3 Selorejo Bend Blitar Regency is one of the bends that do not meet the geometric planning requirements for roads in Indonesia. This research uses quantitative descriptive analysis method. Data collection was carried out using the location survey method for 4 days. Primary data include data on traffic volume, vehicle speed, road equipment, road widening and road geometry. Secondary data on existing traffic and geometric accident data. The results get: (1) traffic characteristics have a maximum volume occurs on Monday at $17221 \mathrm{pcu} /$ day which is dominated by light vehicles (LV) of $46.13 \%$, the average vehicle speed of $47.95 \mathrm{~km} /$ hour with the highest speed is dominated by motorized vehicles (MC) which have an average speed of $62.73 \mathrm{~km} / \mathrm{hour}$ with the highest speed ever recorded in the observation of $87.64 \mathrm{~km} / \mathrm{hour}$, and the highest vehicle density occurs on Monday at 32, 73 smp / km, (2) the geometric condition of the road in some aspects of planning such as the existing superelevation value has a value of $11.50 \%$, while the results of the planning obtained superelevation of $9.89 \%$, the existing transition curve has a length of 40 meters, while the results planning obtained the value of the transition curve along 54.56 meters, and the widening of the existing road has a road width of 0.3 meters, while the results obtained from the planning of the road of 0.7124 meters, (3) factors that cause accidents are dominated by human factors of $57.14 \%$ because the events that are often experienced are high speed and sleepy, vehicle factors of $21.43 \%$ with the causes of events experienced due to brakes blown, overloaded, and broken tires, while the road factor of $21.43 \%$ which is always caused by the slope of the road at the bend.

Keywords: Geometric Road, Bend, Accident Factor, Traffic

Nando Ramadhani Nur Adnan adalah Alumni Jurusan Teknik Sipil Fakultas Teknik UM; E-mail: faan.ramadhani24@gmail.com; Pranoto dan Boedi Rahardjo adalah Dosen Jurusan Teknik Sipil Fakultas Teknik UM; Jalan Semarang No.5 Malang 65145; E-mail: pranoto.ft@um.ac.id dan boedi.rahardjo.ft@um.ac.id 


\section{PENDAHULUAN}

Kecelakaan merupakan permasalahan lalu lintas yang membahayakan jiwa manusia. Menurut Warpani (2002) kecelakaan lalu lintas merupakan suatu peristiwa yang secara disengaja atau tidak, melibatkan kendaraan yang sedang bergerak dengan atau tanpa pengguna jalan lain dan mengakibatkan korban manusia atau kerugian harta benda. Kecelakaan disebut fatal apabila menimbulkan korban jiwa (meninggal dunia). Apabila masalah kecelakaan di jalan raya tidak diperhatikan dengan baik, dikhawatirkan akan terjadi peningkatan jumlah korban kecelakaan dari tahun ke tahun.

Kecelakaan lalu lintas lebih banyak terjadi di daerah tikungan. Zainuri (2010), tikungan adalah garis proyeksi sumbu trase suatu jalan yang tegak lurus pada bidang peta. Menurut Taufiq (2018), jumlah kecelakaan di tikungan jalan 1,5 hingga 4 kali lebih banyak daripada di bagian lurus jalan. Tikungan tajam merupakan lokasi rawan kecelakaan, sementara standar geometrik mengijinkan adanya tikungan tajam tetapi hanya untuk jalan dengan fungsi tertentu dengan kecepatan relatif rendah. Salah satu hal yang menyebabkan terjadinya kecelakaan pada tikungan adalah ketidaksesuaian desain geometrik tikungan dengan standar perencanaan yang berlaku. Hal ini juga diperburuk dengan perilaku berkendara dengan kecepatan tinggi karena tidak semua sifat pengemudi selalu sama. Salah satu daerah rawan kecelakaan dengan kriteria jalan seperti itu terdapat di daerah Blitar di Provinsi Jawa Timur terutama di pada daerah tikungan SDN Selorejo 3 Kabupaten Blitar.

Tikungan SDN 3 Selorejo belum memenuhi persyaratan perencanaan geometrik dan perlengkapan jalan. Berdasarkan tinjauan teknis yang dilakukan oleh Balai Besar Pelaksanaan Jalan Nasional VIII (2018), pada tikungan tersebut memiliki nilai superelevasi sebesar $11,50 \%$. Nilai tersebut melebihi persyaratan yang ditetapkan sebesar $10 \%$ untuk nilai maksimum superelevasi (TPGJAK, 1997). Sedangkan untuk perlengkapan jalan seperti rambu-rambu lalu lintas masih belum ada dan terdapat sedikit penerangan jalan. Selain itu garis marka jalan pada tikungan sudah mulai memudar sehingga membuat beberapa pengendara mendahului kendaraan lain tidak pada lajur yang seharusnya. Permasalahan geometrik di tikungan tersebut terdapat pada perencanaa alinemen horizontal untuk nilai superelevasi yang melebihi persyaratan. Hal tersebut dapat menyebabkan kendaraan menjadi guling karena permukan jalan yang terlalu miring. Sedangkan untuk alinemen vertikal tidak terdapat tinjauan teknis yang menjadi permasalahan karena pada tikungan tersebut memiliki kelandaian yang telah memenuhi syarat. Berdasarkan permasalahan tersebut, maka daerah tikungan SDN 3 Selorejo Kabupaten Blitar dapat dijadikan sebagai studi kasus untuk analisis.

\section{METODE}

Penelitian yang dilakukan merupakan penelitian dengan pendekatan deskriptif kuantitatif. Penelitian ini bertujuan untuk mendeskripsikan atau memaparkan kejadian yang sesuai dengan apa adanya yang terjadi saat ini secara sistematis, akurat, dan faktual tentang sifat-sifat yang teliti. Penelitian ini berupaya untuk mengetahui karakter 
istik arus lalu lintas, menganalisis kondisi geometrik jalan terhadap potensi terjadinya kecelakaan, dan untuk mengetahui faktor-faktor penyebab kecelakaan lalu lintas pada tikungan SDN 3 Selorejo Kabupaten Blitar. Teknik pengumpulan data pada rancangan penelitian ini dimulai dengan mencari informasi dan survei lokasi yang akan diteliti. Data primer meliputi karakteristik lalu lintas (volume lalu lintas, kecepatan kendaraan, dan kepadatan kendaraan), geometrik jalan alinemen horizontal (jari-jari tikungan, superelevasi, lengkung peralihan, dan pelebaran jalan) dan alinemen vertikal (kelandaian), dan rambu-rambu lalu lintas (marka jalan, penerangan, dan kondisi jalan). Sedangkan untuk data sekunder meliputi faktor-faktor penyebab kecelakaan (jumlah kejadian, detail penyebab, usia pelaku, jenis kelamin, kondisi korban, jenis kendaraan, waktu kejadian, dan kondisi cuaca) yang diperoleh dari hasil monitoring evaluasi Kepolisian Resort Blitar dan kondisi geometrik existing tikungan yang diperoleh dari Balai Besar Pelaksanaan Jalan Nasional VIII. Data tersebut kemudian diolah menggunakan program bantu berbasis angka yaitu Microsoft Excel. Selanjutnya data diolah dan diklasifikasikan berdasarkan hari, jenis kendaraan, dan faktor penyebab kecelakaan.

Penelitian ini mengambil lokasi pada ruas jalan Selorejo Kabupaten Blitar, yang mana ruas jalan ini merupakan jalur yang menghubungkan Malang-Tulungagung-Trenggalek. Survei dilaksanakan dilokasi yang dianggap rawan kecelakaan yaitu pada tikungan di SDN 3 Selorejo dengan panjang segmen yang ditinjau sejauh 200 m. Pelaksanaan waktu survei dilakukan selama 4 hari masing-masing hari Sabtu dan hari Minggu yang mewakili hari libur dan hari Senin serta hari Selasa yang mewakili hari kerja. Survei dilakukan mulai jam 06.00-18.00 WIB.

Survei pengamatan di lapangan dilakukan guna mendapatkan gambaran situasi lalu lintas umum mengenai keadaan jalan pada tikungan SDN 3 Selorejo Kabupaten Blitar. Saat melakukan survei lalu lintas harian rata-rata peneliti mengamati perilaku pengguna kendaraan bermotor, jenis kendaraan, kecepatan kendaraan, mengamati dan mendokumentasikan keadaan jalan dan lingkungan (marka jalan, rambu-rambu lalu lintas, dan penerangan jalan). Informasi ini dilakukan untuk mendukung analisa dan interpretasi data kecelakaan, terutama untuk memberikan pernyataan hasil analisa kecelakaan dan gambaran lokasi tikungan serta untuk mengkonfirmasi perkiraan penyebab terjadinya kecelakaan di tikungan SDN 3 Selorejo Kabupaten Blitar. Hasil survei ditinjau dan di analisis terhadap ketentuan dan persyaratan yang telah ditetapkan untuk digunakan pada perhitungan teoritis geometrik jalan pada tikungan. Jika terdapat aspek yang tidak memenuhi persyaratan maka diperlukan saran dan perbaikan untuk meminimalisir terjadinya kecelakaan lalu lintas pada tikungan SDN 3 Selorejo Kabupaten Blitar.

\section{HASIL}

Hasil analisis menjelaskan perhitungan yang telah dilakukan pada survei karakteristik lalu lintas, perbandingan analisis geometrik jalan kondisi existing dan hasil perhitungan, dan faktor-faktor penyebab kecelakaan. Analisis ini memasukkan data-data yang telah diperoleh dan di input didalam program bantu Microsoft Exel. 


\section{KARAKTERISTIK LALU LINTAS}

a) Volume Lalu Lintas (V)

Volume lalu lintas merupakan jumlah kendaraan yang melewati suatu titik tertentu dari suatu segmen atau ruas jalan selama kurun waktu tertentu. Volume lalu lintas digambarkan dengan data volume per interval waktu 15 menit, untuk setiap jenis kendaraan. Hari libur diwakilkan oleh hari Sabtu dan hari Minggu, sedangkan untuk hari kerja diwakilkan oleh hari Senin dan hari Selasa. Berdasarkan hasil survei, diperoleh volume lalu lintas seperti pada gambar 1 sebagai berikut:

Dari hasil analisis volume lalu lintas diperoleh waktu sibuk (peak hour) dan waktu lenggang (off peak hour) seperti pada tabel 1 dan tabel 2 berikut:

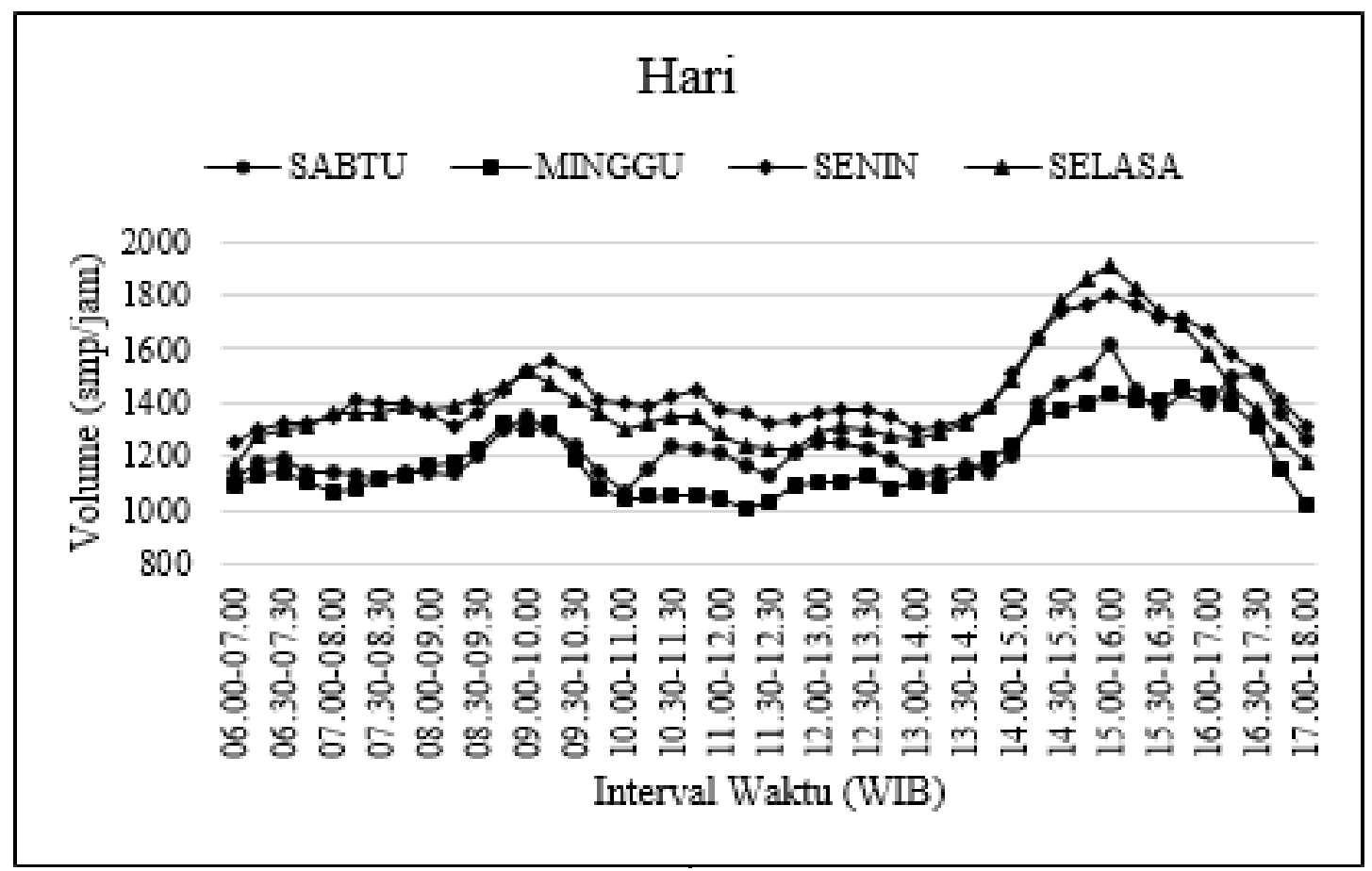

\section{Gambar 1. Grafik Volume Lalu Lintas (smp/jam)}

Tabel 1. Waktu Sibuk (peak hour) dan Lenggang (off peak) Pada Hari Libur

\begin{tabular}{|c|c|c|c|c|c|c|c|c|}
\hline \multirow{2}{*}{ Waktu } & \multicolumn{5}{|c|}{ Jumlah Kendaraan (smp/jam) } & \multirow{2}{*}{$\begin{array}{c}\text { Volume } \\
\text { (smp/jam) }\end{array}$} & \multirow{2}{*}{ Hari } & \multirow{2}{*}{ Pukul (WIB) } \\
\hline & $\mathbf{L V}$ & MHV & LT & LB & MC & & & \\
\hline Sibuk (peak hour) & 815 & 183,6 & 48 & 25,5 & 541,6 & 1613,7 & Sabtu & $15.00-16.00$ \\
\hline $\begin{array}{l}\text { Lenggang (off } \\
\text { peak) }\end{array}$ & 470 & 161,5 & 28,8 & 10,2 & 338 & 1008,5 & Minggu & $11.15-12.15$ \\
\hline
\end{tabular}

Tabel 2. Waktu Sibuk (peak hour) dan Lenggang (off peak) Pada Hari Kerja

\begin{tabular}{|c|c|c|c|c|c|c|c|c|}
\hline \multirow{2}{*}{ Waktu } & \multicolumn{5}{|c|}{ Jumlah Kendaraan (smp/jam) } & \multirow{2}{*}{$\begin{array}{c}\text { Volume } \\
\text { (smp/jam) }\end{array}$} & \multirow{2}{*}{ Hari } & \multirow{2}{*}{ Pukul (WIB) } \\
\hline & $\mathbf{L V}$ & MHV & LT & LB & MC & & & \\
\hline Sibuk (peak hour) & 889 & 289 & 38,4 & 15,3 & 675,2 & 1906,9 & Selasa & $15.00-16.00$ \\
\hline $\begin{array}{l}\text { Lenggang (off } \\
\text { peak) }\end{array}$ & 452 & 200,6 & 12,8 & 10,2 & 492 & 1167,6 & Selasa & $06.00-07.00$ \\
\hline
\end{tabular}




\section{b) Kecepatan (S)}

Kecepatan diperoleh dari hasil bagi panjang segmen jalan dengan nilai rata-rata waktu tempuh kendaraan. Hasil survei pencatatan waktu diperoleh dengan mengambil sampel tiap kendaraan sebanyak 1 kendaraan per interval waktu 15 menit. Dari hasil analisis kecepatan diperoleh nilai kecepatan tertinggi, kecepatan terendah, dan kecepatan rata-rata dari semua jenis kendaraan. Nilai kecepatan tertinggi digunakan sebagai dasar analisis kecepatan rencana pada perhitungan geometrik. Berdasarkan hasil survei diperoleh kecepatan kendaraan seperti pada gambar 2 berikut.

Untuk mengetahui rekapitulasi kecepatan tertinggi, kecepatan terendah, dan kecepatan rata-rata seluruh jenis kendaraan, dapat dilihat pada tabel 3 berikut:

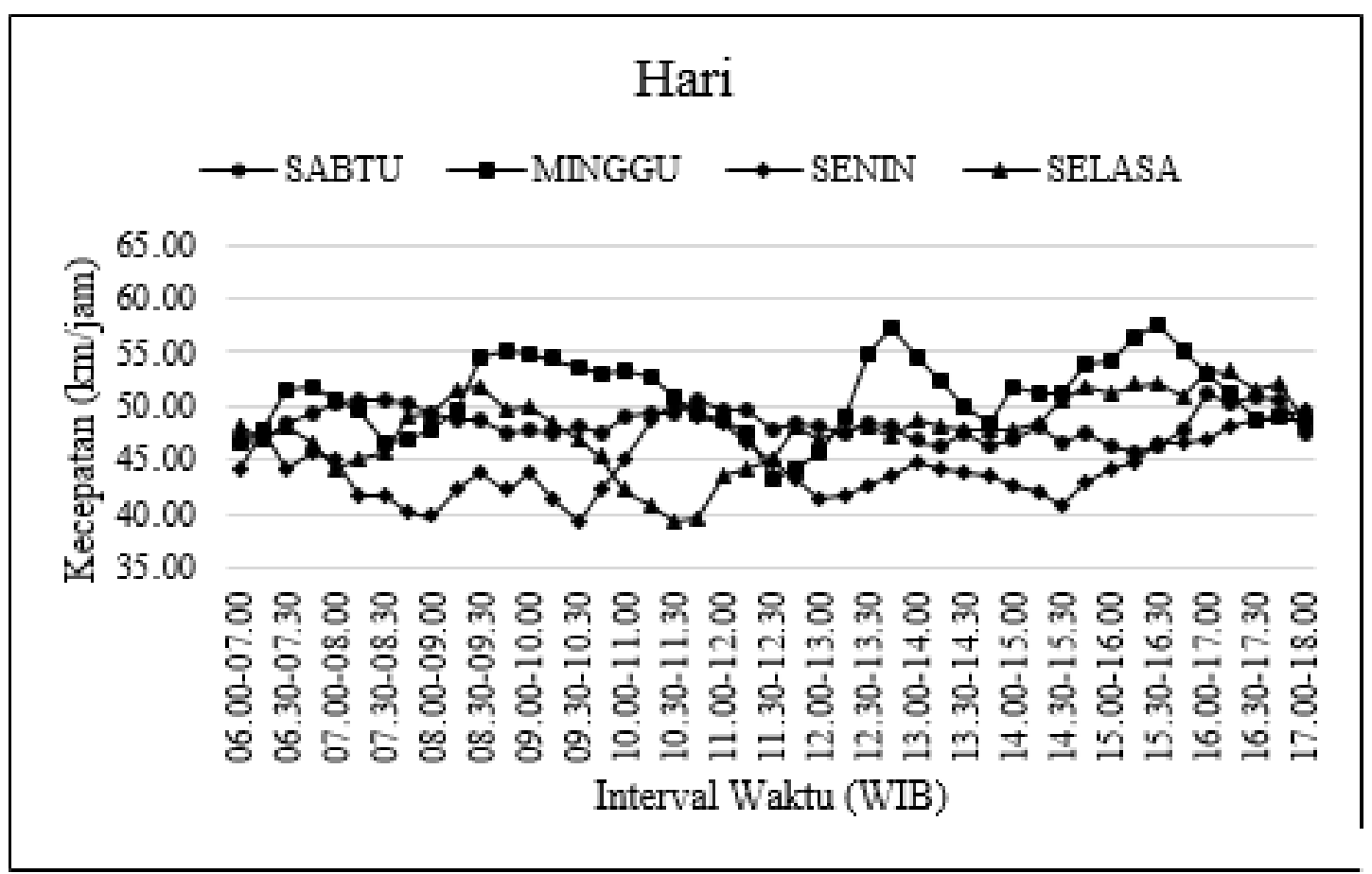

Gambar 2. Grafik Kecepatan Kendaraan (km/jam)

Tabel 3. Rekapitulasi Kecepatan Seluruh Kendaraan

\begin{tabular}{lccc}
\hline \multirow{2}{*}{ Hari } & \multicolumn{3}{c}{ Kecepatan (km/jam) } \\
\cline { 2 - 4 } & Maksimum & Minimum & Rata-Rata \\
\hline Sabtu & 51,25 & 45,58 & 48,38 \\
\hline Minggu & 57,42 & 43,40 & 51,07 \\
\hline Senin & 50,31 & 39,25 & 44,48 \\
\hline Selasa & 53,32 & 39,19 & 47,87 \\
\hline Rata-Rata Kecepatan & & & 47,95 \\
Kendaraan & & & \\
\hline
\end{tabular}




\section{c. Kepadatan (D)}

Kepadatan lalu lintas adalah hal yang penting karena terkait dengan permintaan lalu lintas yang dibangkitkan dari berbagai tata guna lahan pada segmen tertentu jalan. Nilai besaran angka kepadatan diperoleh dari hasil bagi nilai volume lalu lintas dengan kecepatan. Pada umumnya, besaran satuan angka kepadatan dinyatakan sebagai jumlah kendaraan per kilometer atau satuan mobil penumpang per kilometer. Dari hasil analisis kepadatan diperoleh nilai kepadatan tertinggi, kepadatan terendah, dan kepadatan rata-rata. Hasil kepadatan kendaraan berdasarkan gambar 3 berikut.

Untuk mengetahui rekapitulasi kepadatan tertinggi, kepadatan terendah, dan kepadatan rata-rata kendaraan, dapat dilihat pada tabel 4 berikut:

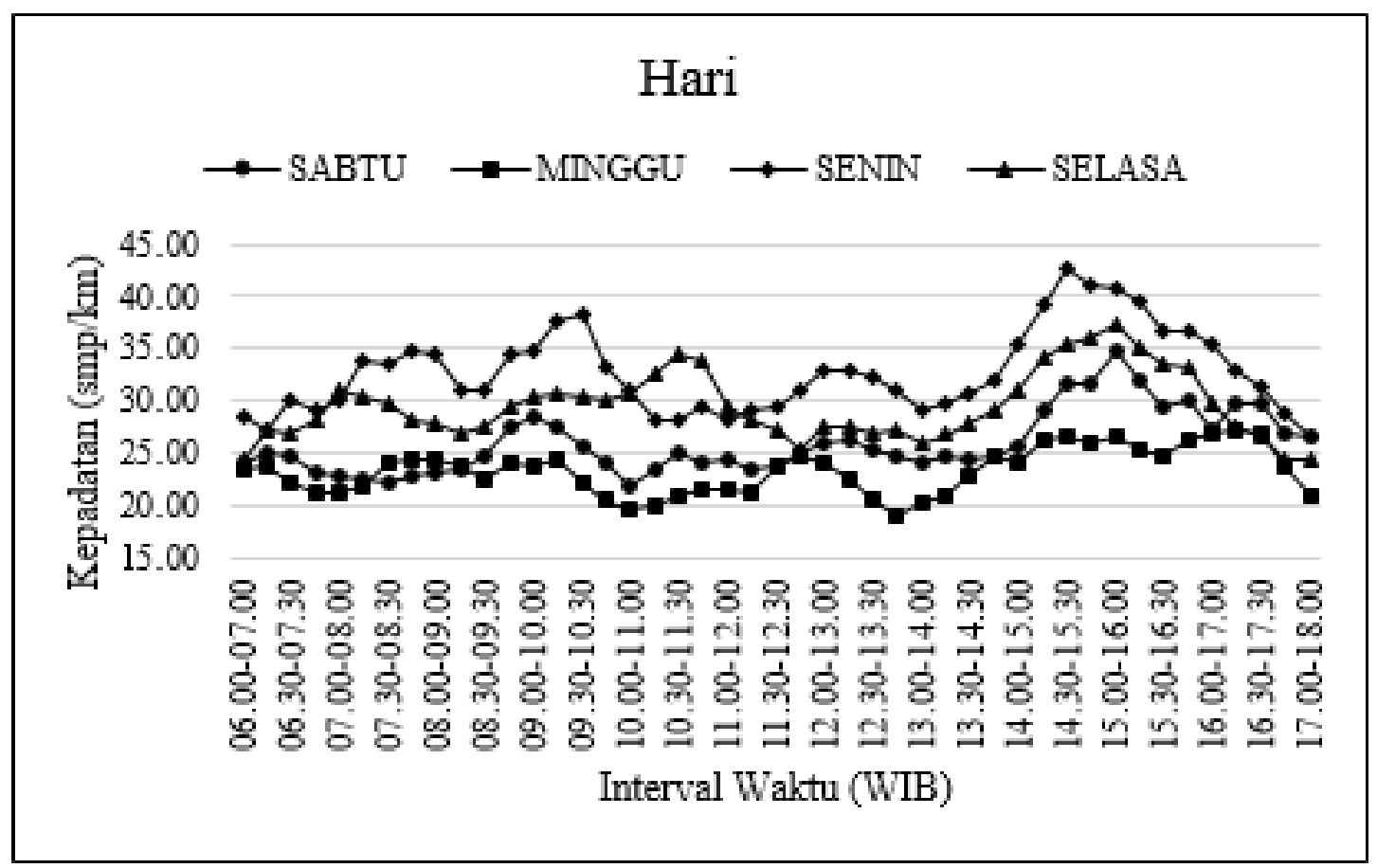

Gambar 3. Grafik Kepadatan Kendaraan (smp/km)

Tabel 4. Rekapitulasi Kepadatan Seluruh Kendaraan

\begin{tabular}{lccc}
\hline \multirow{2}{*}{ Hari } & \multicolumn{3}{c}{ Kepadatan $(\mathbf{s m p} / \mathbf{k m})$} \\
\cline { 2 - 4 } & Maksimum & Minimum & Rata-Rata \\
\hline Sabtu & 34,90 & 21,86 & 25,93 \\
\hline Minggu & 27,27 & 19,00 & 23,25 \\
\hline Senin & 42,70 & 26,54 & 32,73 \\
\hline Selasa & 37,20 & 24,30 & 29,49 \\
\hline $\begin{array}{l}\text { Rata-Rata Kepadatan } \\
\text { Kendaraan }\end{array}$ & & & 27,85 \\
\hline
\end{tabular}




\section{KONDISI GEOMETRIK JALAN}

Analisis geometrik jalan dilakukan guna mengetahui bagian-bagian perencanaan tikungan jalan SDN 3 Selorejo Kabupaten Blitar yang tidak memenuhi syarat terhadap standar ketetapan pada kondisi existing. Analisis dilakukan berdasarkan parameter kecepatan dari hasil survei yang di dapat sebagai acuan kecepatan rencana.

Pada tabel 5 berikut adalah perbandingan nilai teknis kondisi geometrik existing terhadap hasil perhitungan analisis pada tikungan SDN 3 Selorejo Kabupaten Blitar.

Berdasarkan tabel 5 dibawah, pada kondisi existing nilai superelevasi, lengkung peralihan, dan lebar tikungan tidak memenuhi standar persyaratan yang ditetapkan. Sedangkan pada hasil analisis, pelebaran tikungan jalan masih belum memenuhi syarat.

\section{FAKTOR PENYEBAB KECELAKAAN}

Faktor-faktor penyebab kecelakaan lalu lintas diantaranya adalah manusia, kendaraan, jalan, dan lingkungan. Berdasarkan hasil monitoring evaluasi Polres Blitar, faktor penyebab kecelakaan lalu lintas pada tikungan SDN 3 Selorejo Kabupaten Blitar seperti pada gambar 4 berikut:

Tabel 5. Hasil Perbandingan Nilai Teknis Kondisi Geometrik

\begin{tabular}{lccc}
\multirow{2}{*}{ Aspek } & \multicolumn{2}{c}{ Nilai Teknis } & \multirow{2}{*}{ Keterangan } \\
\cline { 2 - 3 } & Existing & Hasil Analisis & \\
\hline Jenis Tikungan & S-C-S & S-C-S & Memenuhi \\
\hline $\begin{array}{l}\text { Kecepatan rata-rata tertinggi kendaraan } \\
\text { (real speed) }\end{array}$ & $57,42 \mathrm{~km} / \mathrm{jam}$ & $60 \mathrm{~km} / \mathrm{jam}$ & Memenuhi \\
\hline Radius tikungan & 125 meter & 125 meter & Memenuhi \\
\hline Superelevasi (e) & $11,50 \%$ & $9,89 \%$ & Memenuhi \\
\hline Lengkung spiral (Ls) & 40 meter & 54,56 meter & Memenuhi \\
\hline Lebar jalan (B) & 6,00 meter & 6,00 meter & Memenuhi \\
\hline Lebar tikungan jalan (b') & 0,30 meter & 0,7124 meter & Tidak Memenuhi \\
\hline Kelandaian & $+5,32 \%$ dan $-3,84 \%$ & $+5,32 \%$ dan $-3,84 \%$ & Memenuhi \\
\hline
\end{tabular}

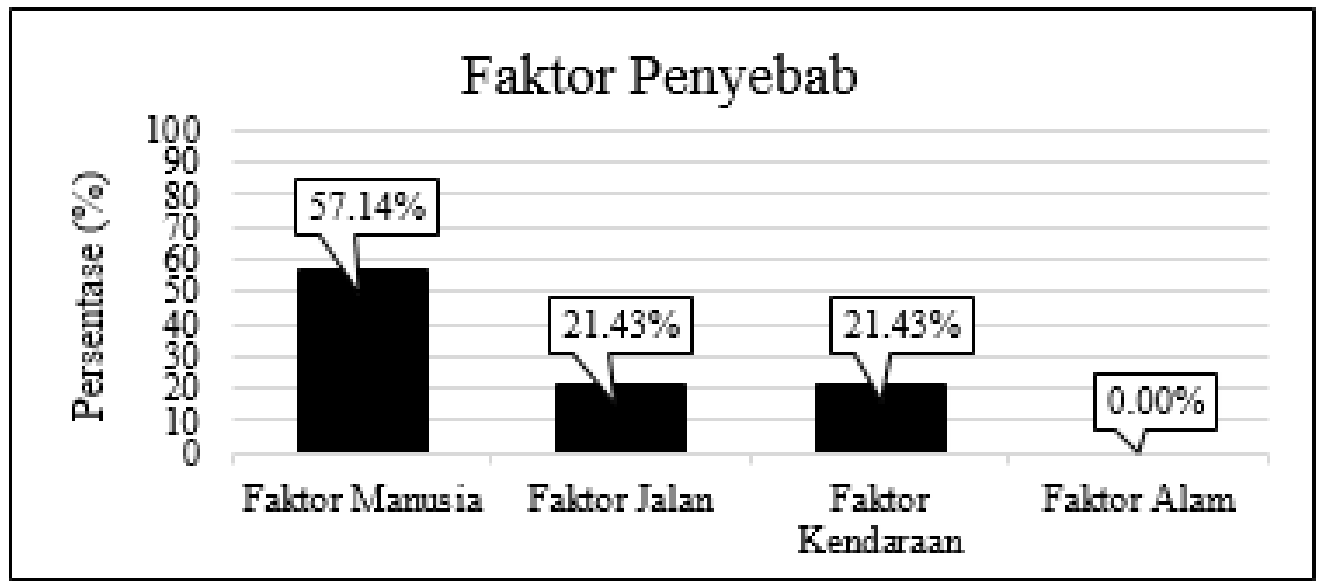

Gambar 4. Diagram Faktor Penyebab Kecelakaan Lalu Lintas 


\section{PEMBAHASAN}

\section{KARAKTERISTIK LALU LINTAS}

\section{1.a) Volume Lalu Lintas (V)}

Nilai volume rata-rata keseluruhan untuk hari libur adalah $14471 \mathrm{smp} /$ hari dan rata-rata nilai volume per jam adalah 1219,6 smp/jam.

Sedangkan nilai volume rata-rata keseluruhan untuk hari kerja adalah $16968 \mathrm{smp} /$ hari dan rata-rata nilai volume per jam adalah 1430 smp/jam. Volume terbesar atau waktu sibuk (peak hour) pada hari libur terjadi pada hari Sabtu pukul 15.00-16.00 WIB dengan jumlah mencapai 1613,7 smp/jam, sedangkan untuk volume terkecil atau waktu lenggang (off peak) pada hari libur terjadi pada hari Minggu pukul 11.15-12.15 WIB dengan jumlah mencapai $1008,5 \mathrm{smp} / \mathrm{jam}$. volume terbesar atau waktu sibuk (peak hour) pada hari kerja terjadi pada hari Selasa pukul 15.00-16.00 WIB dengan jumlah mencapai 1906,9 smp/jam, sedangkan untuk volume terkecil atau waktu lenggang (off peak) pada hari kerja juga terjadi pada hari Selasa pukul 06.00-07.00 WIB dengan jumlah mencapai 1167,6,5 smp/jam.

\section{1.b) Kecepatan (S)}

Kecepatan tertinggi pada hari libur terjadi pada hari Minggu sebesar 57,42 km/jam, sedangkan untuk kecepatan terendah juga terjadi pada hari Minggu sebesar 43,40 km/jam. Rata-rata kecepatan kendaraan pada hari libur untuk seluruh jenis kendaraan sebesar 49,72 $\mathrm{km} / \mathrm{jam}$. Untuk kecepatan tertinggi pada hari kerja terjadi pada hari Selasa sebesar 53,32 $\mathrm{km} / \mathrm{jam}$, sedangkan untuk kecepatan terendah juga terjadi pada hari Selasa sebesar 39,19 $\mathrm{km} / \mathrm{jam}$. Rata-rata kecepatan kendaraan pada hari kerja untuk seluruh jenis kendaraan sebesar 46,18 km/jam. Sedangkan untuk kecepatan rata-rata seluruh jenis kendaraan selama 4 hari waktu pengamatan sebesar 47,95 km/jam.

\section{1.c) Kepadatan (D)}

Kepadatan kendaraan tertinggi pada hari libur terjadi pada hari Sabtu dengan nilai kepadatan sebesar 34,90 smp/km, sedangkan kepadatan terendah terjadi pada hari Minggu dengan nilai kepadatan sebesar $19 \mathrm{smp} / \mathrm{km}$. Untuk kepadatan kendaraan tertinggi pada hari kerja terjadi pada hari Senin dengan nilai kepadatan sebesar 42,70 smp/km, sedangkan kepadatan terendah terjadi pada hari Selasa dengan nilai kepadatan sebesar 24,30 smp/km. Rata-rata kepadatan kendaraan selama 4 hari waktu pengamatan sebesar 27,85 smp/km.

\section{KONDISI GEOMETRIK JALAN}

\section{2.a) Kecepatan Rencana}

Desain geometrik pada tikungan yang tidak memenuhi syarat sangat berpotensi menimbulkan terjadinya kecelakaan. Kecepatan merupakan faktor utama penentu sebagai landasan dasar desain tikungan terhadap faktor keamanan kecelakaan. Kecepatan yang digunakan dalam analisis merupakan kecepatan tertinggi rata-rata dari seluruh jenis kendaraan dalam $\mathrm{km} / \mathrm{jam}$ selama 4 hari waktu pengamatan. Kecepatan tertinggi yang tercatat selama waktu pengamatan terjadi pada hari minggu pukul 15.30-16.30 WIB sebesar 57,42 km/jam. Hari Minggu merupakan hari dengan volume lalu lintas terendah daripada hari pengamatan yang lain. Pada hari minggu volume lalu lintas yang terjadi hanya sebesar 14045 
smp/hari sehingga volume lalu lintas dapat dikatakan lenggang dan membuat kendaraan melaju dengan kecepatan tinggi. Nilai kecepatan tersebut kemudian dibulatkan menjadi $60 \mathrm{~km} / \mathrm{jam}$ sebagai asumsi angka aman terhadap analisis perencanaan yang dilakukan.

\section{2.b) Alinemen Horizontal}

\section{2.b.1. Jari-Jari Minimum (Rmin)}

Hasil analisis mendapatkan nilai Rmin $=112,263 \mathrm{~m}<$ nilai jari-jari existing $=125$ m. Jadi, nilai jari-jari tikungan pada kondisi existing terpenuhi. Menurut Tata Cara Perencanaan Geometrik Jalan Antar Kota (1997), panjang jari-jari minimum untuk VR $=60 \mathrm{~km} / \mathrm{jam}$ adalah $110 \mathrm{~m}$. Nilai Rmin pada perhitungan analisis terpenuhi.

\section{2.b.2. Superelevasi (e)}

Hasil analisis mendapatkan nilai e $=9,89 \%$ $<$ nilai e maks $=10 \%$. Menurut Tata Cara Perencanaan Geometrik Jalan Antar Kota (1997), niai superelevasi maksimum ditetapkan sebesar $10 \%$. Jadi, nilai superelevasi tikungan hasil analisis memenuhi, namun pada kondisi existing berdasarkan hasil survei dari Balai Besar Pelaksanaan Jalan Nasional VIII mendapatkan nilai superelevasi di tikungan SDN 3 Selorejo Kabupaten Blitar tidak memenuhi persyaratan. Nilai superelevasi existing pada tikungan tersebut sebesar $11,50 \%$.

\section{2.b.3. Lengkung Peralihan (Ls)}

Hasil analisis mendapatkan nilai $\mathrm{Ls}=$ $54,56 \mathrm{~m}>$ nilai Ls existing $=40 \mathrm{~m}$. Menurut Bina Marga, panjang lengkung peralihan (Ls) minimum untuk VR $=60 \mathrm{~km} / \mathrm{jam}$ dan e $=9,89 \%$ adalah $50 \mathrm{~m}$. Jadi, nilai Ls pada perhitungan hasil analisis terpenuhi. Sedangkan nilai Ls existing tidak terpenuhi.

\section{2.b.4. Pelebaran Jalan (b')}

Hasil survei lapangan mendapatkan nilai $\mathrm{b}^{\prime}=0,3 \mathrm{~m}<$ hasil analisis perhitungan $\mathrm{b}^{\prime}=$ 0,7124 m. Hasil tersebut menunjukkan bahwa pelebaran jalan pada tikungan SDN 3 Selorejo Kabupaten Blitar tidak memenuhi terhadap hasil perhitungan analisis. Menurut Tata Cara Perencanaan Geometrik Jalan Antar Kota (1997), pelebaran tikungan minimum untuk $\mathrm{VR}=60 \mathrm{~km} / \mathrm{jam}$ dan $\mathrm{R}=125 \mathrm{~m}$ adalah 1,4 m. Jadi, pelebaran jalan pada tikungan SDN 3 Selorejo Kabupaten Blitar tidak terpenuhi.

\section{3) Alinemen Vertikal}

Analisis kelandaian dilakukan secara langsung berdasarkan hasil survei yang dilakukan oleh Balai Besar Pelaksanaan Jalan Nasional VIII. Nilai kelandaian pada tikungan SDN 3 Selorejo Kabupaten Blitar sebesar $+5,32 \%$ dan $-3,84 \%$ dari arah Malang ke Tulungagung (Timur-Barat). Hasil tersebut telah memenuhi persyaratan Bina Marga yang menjelaskan kelandaian maksimum untuk VR $=60 \mathrm{~km} / \mathrm{jam}$ sebesar $8 \%$.

\section{FAKTOR PENYEBAB KECELAKAAN}

Kasus kecelakaan lalu lintas pada tikungan SDN 3 Selorejo Kabupaten Blitar di analisis dari tahun 2009 hingga tahun 2018 dengan jumlah total 14 kejadian kecelakaan lalu lintas. Faktor penyebab kecelakaan lalu lintas pada tikungan SDN 3 Selorejo Kabupaten Blitar yang pertama adalah faktor manusia dengan persen- 
tase sebesar $57,14 \%$ atau sebanyak 8 kejadian.

Faktor yang kedua adalah faktor kendaraan sebesar $21,43 \%$ dan faktor jalan yang juga memiliki persentase sama sebesar $21,43 \%$ dengan jumlah kecelakaan masing-masing sebanyak 3 kejadian. Untuk faktor lingkungan tidak terdapat penyebab pada kecelakaan yang terjadi.

\section{SIMPULAN}

Volume lalu lintas pada hari kerja lebih tinggi daripada hari libur. Volume jumlah kendaraan selalu di dominasi oleh kendaraan bermotor (motor cycle). Sedangkan untuk volume dalam satuan mobil penumpang (smp) di dominasi oleh kendaraan ringan (light vehicle) karena memiliki nilai emp yang lebih besar daripada kendaraan bermotor (motor cycle). Kendaraan bermotor merupakan jenis kendaraan yang memiliki rata-rata kecepatan tertinggi daripada jenis kendaraan yang lain. Kecepatan kendaraan tertinggi terjadi pada hari minggu dengan kecepatan sebesar 57,42 km/jam. Hari Minggu mrupakan hari dengan volume lalu lintas yang lenggang sehingga kendaraan cenderung melaju dengan kecepatan tinggi. Volume lalu lintas berbanding lurus dengan kepadatan kendaraan. Jika volume lalu lintas sedang tinggi, maka kepadatan kendaraan juga akan tinggi.

Kondisi geometrik jalan existing pada tikungan yang berpotensi menyebabkan kecelakaan terdapat pada aspek superelevasi, lengkung peralihan, dan pelebaran jalan. Nilai superelevasi melebihi batas maksimum dari standar yang ditetapkan sebesar 11,50\%, hal tersebut dapat menyebabkan kendaraan yang melintasi tikungan akan mengalami guling terutama pada kendaraan dengan beban tonase tinggi. Lengkung peralihan sebesar 40 meter, nilai tersebut kurang dari syarat yang ditetapkan. Kurangnya nilai lengkung peralihan dapat membuat pengemudi kaget atau terkejut saat mengalami perubahan tikungan yang terlalu dekat. Pelebaran jalan pada tikungan sebesar 0,3 meter, sedangkan syarat ketetapan pelebaran jalan pada tikungan untuk untuk $\mathrm{VR}=60$ $\mathrm{km} / \mathrm{jam}$ dan $\mathrm{R}=125 \mathrm{~m}$ adalah 1,4 $\mathrm{m}$. Lebar jalan yang tidak terpenuhi dapat menyebabkan kendaraan keluar jalur lintasan pada jalan.

Faktor-faktor penyebab kecelakaan pada tikungan SDN 3 Selorejo Kabupaten Blitar di dominasi oleh faktor manusia sebesar 57,14\% dengan sebab kecelakaan yang paling sering ditemui diakibatkan oleh kecepatan tinggi dan mengantuk, faktor jalan sebesar 21,43\% dengan penyebab kecelakaan yang selalu terjadi karena miring pada tikungan, dan pada faktor kendaraan sebesar 21,43\% dengan sebab kecelakaan terjadi diakibatkan oleh rem blong, muatan berlebih, dan ban pecah.

\section{DAFTAR RUJUKAN}

Balai Besar Pelaksanaan Jalan Nasional VIII. 2018. Kajian Teknis Kemiringan Jalan Raya Selorejo Kabupaten Blitar (Depan SDN Selorejo 3). Sidoarjo: Bina Marga. Departemen Pekerjaan Umum Direktorat Jen deral Bina Marga. 1997. Tata Cara Peren canaan Geometrik Jalan Antar Kota. Ja karta.

Markas Besar Kepolisian Negara Republik Indonesia Korps Lalu Lintas. 2013. Polan tas Dalam Angka 2013. Jakarta : Kepoli sian Negara Republik Indonesia. 
Sukirman, S. 1999. Dasar - Dasar Perenca naan Geometrik Jalan Raya. Bandung: Nova.

Taufiq, N.F., M. Ferdian Hidayat, Amelia Kusuma I, Djoko Purwanto. 2018. Karak teristik Kecelakaan Lalu Lintas Pada Ti kungan Rawan Kecelakaan Di Jalan Pan tura Jawa Tengah. Departemen Teknik Sip il, Fakultas Teknik Universitas Dipone goro.
Warpani, P. Suwardjoko. 2002. Pengelolaan Lalu Lintas dan Angkutan Jalan. Bandung: Penerbit ITB.

Zainuri, A. 2010. Perencanaan Geometrik Jalan Terhadap Tingkat Kecelakaan, (On line), (https://iamnotthoseman.wordpress. com/2010/07/08/perencanaan-geometrikjalan-alinyemen/), di akses 5 Februari 2019. 
32 JURNAL BANGUNAN, VOL. 25, NO.1, MARET 2020: 21-32 